The University of San Francisco

USF Scholarship: a digital repository @ Gleeson Library |

Geschke Center

Economics, Law, and International Business

School of Management

1993

\title{
Strict Liability for Sellers of Used Products: A Conceptual Rationale and Current Status
}

\author{
Karl Boedecker \\ University of San Francisco, boedecker@usfca.edu \\ Fred W. Morgan
}

Follow this and additional works at: http://repository.usfca.edu/elib

Part of the Business Law, Public Responsibility, and Ethics Commons

\section{Recommended Citation}

Karl Boedecker and Fred Morgan, "Strict Liability for Sellers of Used Goods: A Conceptual Rationale and Current Status," Journal of Public Policy \& Marketing, 12 (Fall), 178-187. 1993

This Article is brought to you for free and open access by the School of Management at USF Scholarship: a digital repository @ Gleeson Library | Geschke Center. It has been accepted for inclusion in Economics, Law, and International Business by an authorized administrator of USF Scholarship: a digital repository@Gleeson Library| Geschke Center. For more information, please contact repository@usfca.edu. 


\title{
Strict Liability for Sellers of Used Products: A Conceptual Rationale and Current Status
}

\author{
Karl A. Boedecker and Fred W. Morgan
}

\begin{abstract}
Marketers of used products face uncertainty in the legal environment because of the inconsistent ways their offerings are treated with respect to strict product liability. The authors analyze the conceptual underpinnings of strict liability to assess its applicability to used goods. Then they examine litigated cases to present an overview of current judicial treatment of defective used products. Finally, they discuss policy issues related to used products in the context of both the law and marketing.
\end{abstract}

$\mathbf{T}$ he doctrine of strict product liability for sellers of new goods developed during the mid-twentieth century in large part out of vigorous academic debate and discussion [Priest 1985]. William Prosser [1960] championed the strict product liability doctrine in his seminal article, "Assault Upon the Citadel." He subsequently synthesized the academic dialogue with the relevant judicial opinions as Reporter for the Restatement (Second) of Torts [1965]. ${ }^{1}$ By then, California had openly embraced strict liability for personal injury recoveries in defective product cases [Greenman v. Yuba Power Products 1963]. Other jurisdictions soon followed, and Prosser [1966] eventually proclaimed that the "citadel had fallen."

Subsequent issues surrounding strict liability have centered on the extent to which the doctrine should apply. For example, should marketers of services be subjected to strict liability in a manner similar to their product-oriented counterparts [Morgan 1987]? Should nonmanufacturing franchisors be held to a strict liability standard for the defective output of their franchisees [Hadfield 1990]? A related question concerns sellers of used goods-should they be strictly liable for injuries caused by the products they sell but have typically not manufactured?

This question is approached here by considering the theory of strict product liability as originally conceived by torts scholars and later embodied in section 402A of the $R e$ statement [1965]. A brief examination of some leading cases illustrates how judges relied on those theoretical concepts to forge modern product liability law. We then review recent case law involving questions of strict seller liability for product-related injuries from used goods. ${ }^{2}$ We also consider to what extent the same circumstances (marketing, economic, and social) that gave rise to strict product liability for new goods are also relevant for used goods.

Karl A. Boedecker is Professor of Business Administration, McLaren College of Business, University of San Francisco. FRED W. MoRgan is Professor of Marketing, College of Business Administration, University of Oklahoma.

\section{Development of the Concept of Strict Product Liability}

At the beginning of the twentieth century, rapid industrialization and expanding markets had resulted in multilevel distribution systems that placed intermediaries between manufacturers and final buyers. These distribution channels, coupled with "privity of contract," 3 effectively precluded recoveries in product injury cases. Unless a consumer could establish either an enforceable warranty on the part of the immediate supplier or negligence in designing, producing, or failing to inspect the defective item, he or she had to absorb the loss from the injury.

The New York Court of Appeals began to erode the privity doctrine in personal injury actions in MacPherson $v$. Buick Motor Company [1916] by extending a manufacturer's liability beyond its immediate purchaser (most often a wholesaler or retail dealer). Though some jurisdictions followed MacPherson's lead, they initially did so only for manufacturers of "imminently dangerous" products, which typically included food, drugs, and automobiles. Even in those jurisdictions adopting MacPherson, the privity requirement remained for injuries from products not classified as "inherently dangerous," and for all such actions in other jurisdictions. Furthermore, injured consumers often had great difficulty proving negligence against manufacturers and others within the distribution chain.

Tort scholars became disenchanted with negligence as the sole basis for product injury claims, arguing that the negligence doctrine alone would not meet all the emerging public policy objectives of tort law. In his 1941 treatise, Prosser [p. 1141] set forth what he regarded as "all of the valid arguments supporting strict liability":

- The public interest in the utmost safety of products;

- The demand for the maximum protection of the consumer;

- The assurance to consumers that is implied by placing the goods on the market for human use;

- The consumer's justifiable reliance on the apparent safety of a product that he or she finds on the market because the defendant has put it there;

- The consumer being the seller's ultimate objective; and 
- The desirability of avoiding "circuity of action" and allowing instead direct recovery from intermediaries.

In his role as Reporter for the Restatement (Second) of Torts [1965], Prosser distilled the previous 30+ years of academic debate and what he regarded as the leading judicial opinions about strict product liability into $\$ 402 \mathrm{~A}$. Nonetheless, injured parties still faced formidable problems of proof, only somewhat alleviated by the rule of res ipsa loquitur, and reaching intermediaries such as wholesalers remained troublesome.

Some courts expanded manufacturers' and intermediaries' liabilities through changes in warranty law. Though he roundly criticized warranty law as a means for achieving strict liability to consumers, Prosser [1966, p. 791] hailed a warranty case as "the fall of the citadel of privity" [Henningsen v. Bloomfield Motors 1960]. Henningsen upheld the validity of product injury claims brought by the spouse of a new car purchaser against both the manufacturer and the dealer. Pointing to "modern marketing conditions," the Henningsen court found that an implied warranty of merchantability, i.e., that goods are fit to use for the general purpose for which they were designed, attached to the car and followed it through the distribution system to the buyer and members of his household. None of the traditional contract defenses, particularly privity and warranty disclaimer provisions, insulated the manufacturer or its dealer from liability. In justifying its decision, the court stated its intent to allocate losses caused by injuries from defective products to the parties best able to control the risks and equitably allocate the costs [Henningsen v. Bloomfield Motors 1960].

Justice Roger Traynor of the California Supreme Court pioneered open judicial acceptance of the strict liability doctrine, which had first appeared in reported cases that involved food and beverage products [Prosser 1960, pp. $1103-10]$. As early as 1944 , in a concurring opinion that none of his fellow justices joined, Traynor used public policy arguments to advocate the adoption of strict liability for defective products [Escola v. Coca-Cola Bottling Co. 1944]. Three years later he unsuccessfully urged his brethren to impose strict liability "openly and not by spurious application of [res ipsa] rules" [Gordon v. Aztec Brewing Co. 1947].

By 1963, however, Traynor's position, set forth in Greenman v. Yuba Power Products [1963], became law in California. His opinion, which drew heavily on academic articles and treatises, essentially matched the synthesis that Prosser had developed and would soon appear as $\$ 402 \mathrm{~A}$ of the $R e$ statement [1965]. ${ }^{4}$ This strict liability doctrine had become law in 28 states by 1971; 40 had embraced it by 1976 [Rabin 1990, p. 81]; and 48 states presently utilize some form of strict liability in cases stemming from productrelated injuries. ${ }^{5}$

As currently applied, strictly liability refers to liability without reference to the defendant's behavior; instead, it examines the nature of the allegedly defective product. That is, to recoup damages, the plaintiff consumer must show that the defendant marketer's product caused the injury in question. Furthermore, the injured plaintiff must prove that the product was defective in some manner (e.g., unsafely designed, improperly manufactured, accompanied by inade- quate warnings) when the consumer acquired it. In addition, product liability law varies from state to state; hence, each is free, for example, to determine how strict liability is to be applied within its boundaries. Consequently, there is no national strict liability standard, though the Restatement [1965] is widely disseminated.

\section{Strict Product Liability in Used Goods Transactions: Case Law}

Neither the voluminous academic literature nor the judicial opinions that resulted in strict liability as described here directly addressed used goods transactions. The Restatement [1965, §402A] does not employ the term "used goods" or anything similar, yet $\$ 402 \mathrm{~A}$ leaves ample room for courts to bring used goods within its ambit. In general, however, the role of strict liability for sellers of used goods has not found widespread acceptance in the courts during the 27 years since the publication of the Restatement [1965, $\$ 402 \mathrm{~A}]$. Most states that have examined strict liability claims against sellers of used products have ruled in favor of the sellers.

In discussing used goods cases from various jurisdictions, we have organized the judicial opinions according to the principal rationale utilized to resolve the dispute. These arguments are summarized in Exhibit 1.

\section{Seller Knowledge—Actual or Imputed}

\section{Occasional Seller Rationale}

Subsections (1)(a) and (1)(b) utilize the word "seller," but do not specifically refer to new products or explicitly exclude used goods marketers. Comment (f) [Restatement 1965, \$402A], "Business of Selling," similarly begs the used goods question. It excludes "the occasional seller," i.e., one who does not sell the product in question "as part of his business." This would apply, for example, to the person who sells his or her private automobile to either a neighbor or a used car dealer.

No jurisdiction holds one-time "casual sellers" of used goods to a strict liability standard. Courts faced with that prospect have relied on that portion of Comment ( $f$ ) [Restatement $1965, \S 402 \mathrm{~A}]$ which excludes such parties, though this comment does provide that "it is not necessary that the seller be engaged solely in the business of selling such products"' [cf. Bailey v. ITT Grinnell 1982; Gorath v. Rockwell International 1989]. This comment also includes a broad policy rationale, however, which might be read to apply to one in the business of selling used goods:

The basis for the rule is the ancient one of the special responsibility for the safety of the public undertaken by one who enters into the business of supplying human beings with products which may endanger the safety of their persons and property, and the forced reliance upon that undertaking on the part of those who purchase such goods.

This raises more difficult questions regarding sales of equipment previously used in the seller's business. A worker sought damages from the Boeing Company for injuries caused by a used hydraulic planer that Boeing had sold 
Exhibit 1. Rationale Utilized by Various Jurisdictions to Assess Liability for Used Products Sellers

Rationale

Seller Knowledge-

Actual or Imputed

Occasional Seller

Resellers' Actions

Duty to Warn

Legal Issues

Causation

Statutory Preemption

Public Policy

Chain of Distribution

Fundamental Arguments or Logic

States

Occasional sellers are not strictly liable for personal injuries related to the products they sell because they are not regarded as product experts.

Occasional sellers are people or organizations who are not in the business of routinely selling products. Classic consumer examples involve selling a lawnmower to a neighbor, an automobile to a friend, or various products at a garage sale. Determining whether an organization is an occasional seller is sometimes difficult and depends on the frequency with which such sales occur as well as the relative revenues resulting from such sales.

The actions of the used product seller can be determinative if they indicate that the seller knew or should have known about the product's dangerous propensities. If the product defect was caused by the seller's reconditioning or repair work, liability will attach.

Duty to warn obligations arise when the used product seller has knowledge about the product's dangerous characteristics that may not be obvious to buyers. If the seller's knowledge clearly exceeds that of the buyer, a duty to warn is more likely to exist.

Causation generally focuses on evidence regarding when the defect actually came into being. The defense will argue that the defect could easily have existed prior to the used product's seller coming in contact with the item. This is a compelling argument if the defendant has not modified or serviced the product but merely resold it.

Certain states have enacted or are considering legislation exempting used goods sellers from strict liability actions. The language in documents supporting these statutes general includes many of the arguments mentioned herein, particularly those regarding minimum seller knowledge about product defects.

The distribution chain arguments essentially holds the entire channel responsible for damages because it is the channel that results in products reaching final consumers. Thus liability passes back up the channel to the used goods seller. The channel is therefore responsible for the safety of the products it places in the marketplace. This is the same policy argument used to justify strict liability for sellers of new products.
Massachusetts, Michigan, Minnesota, New Jersey, New York, Ohio, Texas, Washington, Wisconsin

\section{Alaska, Arkansas, Georgia, Kansas, New Hampshire, New Jersey, South Dakota, Wisconsin \\ California, Florida, Illinois, Indiana, Iowa, Wisconsin}

\author{
Kansas, Louisiana, \\ Mississippi, South Carolina, \\ Missouri, Oklahoma, \\ Pennsylvania, Wisconsin
}

Idaho Arizona, New Jersey,
Oregon, Washington to his employer [Thompson v. Rockford Machine Tool Co. 1987]. The Washington Court of Appeals held that the $R \boldsymbol{e}$ statement [1965, $\$ 402 \mathrm{~A}]$ applied and found a material issue of fact as to whether defendant Boeing, an aircraft manufacturer, was a dealer in used products when it sold the planer. In so finding, the court noted that Boeing maintained a separate department that handled its used equipment sales. Other relevant evidence included the number of items sold, revenue generated, and the amount of company resources devoted to used equipment sales [Stiles v. Batavia Atomic Horseshoes 1992].

A similar outcome transpired in Galindo v. Precision American [1985]. A trial court ruled in favor of the seller of a used sawmill trimmer that had injured an employee of the firm purchasing the device. The Fifth Court of Appeals reversed this decision and remanded the case for the trial court to determine if the marketing of used products was a routine part of the defendant's business operations.
In contrast, a New York court found that General Electric was no more than an occasional seller when it disposed of a high-speed grinding mill in a surplus equipment sale [Sukljian v. Charles Ross \& Son Co. 1986]. The court declined to hold General Electric strictly liable for subsequent injuries caused by the mill, even though the case involved more than the single or isolated sale described in Comment (f) [Restatement 1965, \$402A]. The court also noted that General Electric had the facilities to repair such equipment but had not done so because it had been unaware of the defect that subsequently injured the plaintiff [cf. Bevard $v$. Ajax Manufacturing 1979; Santiago v. E.W. Bliss 1985].

As expected, someone in the business of regularly selling used products can readily be held to a strict liability standard. The plaintiff in Nelson v. Nelson Hardware [1991] recovered from the retailer who had sold him a used firearm that turned out to be defective. The retailer bought and sold both new and used guns, though he did not stock new mod- 
els of the weapon in question. The Wisconsin Supreme Court found the retailer to be a "seller" for purposes of $\$ 402$ A of the Restatement [1965] [cf. Ferragamo v Massachusetts Bay Transportation Authority 1985].

\section{Resellers' Actions Rationale}

When the seller has rebuilt or reconditioned products that it then sells, strict liability generally applies. A similar consensus exists when the seller's defective repair work has caused injuries [Shapo 1990]. The results are less certain when the seller reconditions products utilizing parts purchased from a third party.

In Realmuto v. Straub Motors [1974], the New Jersey Supreme Court held that a used car dealer was strictly liable for injuries from defective work, repairs, or replacements made on a vehicle before reselling it. Other courts have either followed this approach or cited it approvingly in related decisions [cf. Shapo 1990, $\$ \S 18.13-18.16$; Crandell v. Larkin and Jones Appliance 1983; Kodiak Electric Association v. Delaval Turbine 1984].

The buyer plaintiff has even stronger arguments when the seller is evasive or dishonest about the nature of the repair work. In Petrus Chrysler-Plymouth v. Davis [1984], the defendant's employee said that an automobile's wiring had been repaired when, in fact, nothing had been done. The consumer recovered when the defective part caused a fire.

Alternatively, reseller repair activity does not automatically result in the plaintiff's recovery. In Barris v. Eddy's Toyota of Wichita [1988], the left rear axle of the plaintiff's vehicle was repaired by the defendant. When the axle failed, the plaintiff sued on the basis of strict liability and breach of warranty. The federal district court of Kansas granted the defendant's summary motion ${ }^{6}$ with respect to the strict liability claim, stating that the plaintiff consumer had failed to provide any evidence that the defendant had known that the repair parts might be defective [cf. Bennett v. Matt Gay Chevrolet Oldsmobile 1991; Brigham v. Hudson Motors 1978]. In addition, other evidence indicated that the auto had been operated beyond its design limits.

An analogous outcome occurred in Rolph v. EGI Companies [1991]. The user of a bending roll machine sued both the machine's manufacturer and the firm that reconditioned the machine at the request of the user's employer. The Wisconsin Supreme Court ruled that the key element was that the reconditioner did not sell the machine but merely reconditioned it. Had the machine been resold, i.e., "placed into the stream of commerce," by the reconditioner, the firm would probably have been held strictly liable.

\section{Duty to Warn Rationale}

Resellers who do not repair or maintain used products could, nevertheless, have a duty to warn buyers about product-related dangers or problems. In Sell v. Bertsch [1984] the used machinery seller was found to have no duty to repair a 40-year-old rolling machine that subsequently injured a buyer's employee. But the defendant was denied summary judgment when the court ruled that the reseller's possible duty to warn the buyer about the dangerous operating features of the used machine was a jury question. The same outcome was reached with respect to a used printing press in Josephs v. Harris Corp. [1982].

The plaintiff was unable to recover in Burrows v. Follett and Leach [1983], even though a guard was missing from a rotating shaft on a used corn picker at the time of purchase. The plaintiff buyer had apparently noticed that the guard was missing, making the danger obvious to him and thereby obviating the need for the defendant to warn him about the missing guard. The seller did not ordinarily purchase used equipment for resale, but did occasionally accept such machinery in trade for new equipment.

In Pridgett v. Jackson Iron \& Metal [1971] the plaintiff was injured while trying to cut open steel drums with an acetylene torch. Among other claims, the plaintiff argued that the defendant who sold him the used drums had a duty to warn of the dangers involved in working around these used containers. The Mississippi Supreme Court rejected this contention, noting that the plaintiff had considerable experience working with this type of drum. In fact, the plaintiff had specified this particular type of drum when placing the order with the defendant scrap metal dealer [cf. Buckbee v. Rockwood Insurance 1989].

Industry custom with regard to used goods can also lead to a verdict in favor of defendant used goods sellers. In Mayberry v. Akron Rubber Machinery [1979], the defendant supplied Mayberry with several obsolete parts to be used in assembling a rubber mixing mill. Since the buyer was an expert with regard to these parts and had purchased similar parts elsewhere, the seller had no duty to warn about possible dangers. Apparently it was customary for buyers and sellers of such components to acquire them on an "as is" basis without inspections or warnings [cf. Ikerd v. Lapworth 1970; Williams v. Nuckolls 1982; Shirey v. U.S. 1984].

\section{Legal Issues}

\section{Causation (Timing of Defect) Rationale}

A majority of the courts considering strict liability for used goods sellers have adopted the position of the Illinois $\mathrm{Su}$ preme Court as set forth in Peterson v. Lou Bachrodt Chevrolet $C o$. [1975]. ${ }^{7}$ Absent allegations that defects in the braking system existed in a used car when it left the dealer or that the dealer had created the defects, the court declined to subject the defendant used car dealer to strict liability. Doing so, the majority declared, would make the dealer an insurer against defects that had come into existence after the product had left the original chain of distribution and come under control of one or more consumers.

In Tauber-Arons Auctioneers v. Superior Court [1980], a California appellate court likewise declined to apply strict liability to used goods sales where no proof existed that the defendant seller had created the defect that caused plaintiff's injuries. A worker had sued the seller of a used planer that caused his injuries. The court noted that the plaintiff had not presented any other bases, such as salespersons' statements or promotional brochures, that would have supported justifiable expectations regarding the safety, quality, and durability of the planer. Furthermore, the court regarded a used goods dealer as outside the "enterprise" that produces and distributes the new product to consumers. Con- 
sequently, there was no continuing business relationship between the ordinary used machinery dealer and the manufacturer that would have allowed the former to make adjustments for the costs of protecting itself against strict liability.

Similarly, in LaRosa v. Superior Court [1981], another California court rejected strict liability when defendant seller of a used punch press showed that it did not cause the product defect in question and had expressly disclaimed any responsibility for its condition. The court also observed that used goods buyers "consciously" traded off quality for lower price. Courts in many other states have also declined to impose strict liability for latent product defects that the used goods dealer neither caused nor could have discovered by reasonable and customary inspection [cf. Keith v. Russell T. Bundy \& Associates 1986; Grimes v. Axtell Ford Lincoln-Mercury 1987].

In order to assess properly the issues of timing of the defect, the Supreme Court of Wisconsin reversed a circuit court's summary judgment in favor of a defendant automobile lessor in Kemp v. Miller 1990. Here the plaintiff was injured by an allegedly defective rented automobile. The circuit court determined that the lessor was not strictly liable because it was neither a manufacturer nor seller of automobiles; moreover, there was insufficient evidence to determine when the defect occurred. The supreme court disagreed with both of these conclusions and ordered a trial to determine when the defect arose.

\section{Statutory Preemption Rationale}

Occasionally statutes have been interpreted to limit strict liability actions for used products. For example, the Idaho legislature has enacted a statute that excludes "commercial seller of used products" from the definition of product seller [Peterson v. Idaho First National Bank 1990]. Several other states are also considering such exclusionary language.

\section{Public Policy-Chain of Distribution Rationale}

The leading case for invoking strict liability in used goods transactions is the New Jersey case Turner $v$. International Harvester Co. [1975]. Plaintiff's decedent had purchased a used truck from defendant truck dealership. Decedent had raised the cab to work on the engine and, while doing so, the cab fell and killed him. In addressing the question of strict liability for defendant seller of the used truck, the court discussed policy considerations. It identified them as cost spreading and buyers' justifiable expectations of safety, quality, and durability. The latter would be lower for used goods and might vary according to the knowledge or sophistication of the particular buyer. This raised a factual issue under the "unreasonably dangerous" provision of $\$ 402 \mathrm{~A}$ of the Restatement [1965]. In any event, the court said, a seller should bear responsibility for " safety defects, whether known or unknown at the time of sale, present while the machine was under his control." Thus, the Turner decision used an enterprise liability theory (i.e., distribution channel as an overall business enterprise) to hold used goods sellers strictly liable for defects, including latent ones, that existed when the product was under the seller's control. $^{8}$

Arizona took the same approach in Jordan v. Sunnyslope Appliance [1983], a case that involved a used propane fuel tank with a defective shut-off valve that caused an explosion that destroyed plaintiff's house. The opinion followed Turner, noting with approval the observation that used products buyers still expect safety when purchasing a serviceable product as opposed to junk parts. It further agreed with the enterprise liability theory as the basis for invoking strict liability and explicitly stated that a seller need not be in the "initial chain" of distribution to be regarded as part of the enterprise. The court also stated that used goods sellers as a class could shift losses, distribute costs, and insure against risks. ${ }^{9}$ [See also Thompson $v$. Rockford Machine Tool Co. 1987.]

\section{Applying Strict Liability to Used Products Transactions}

\section{Legal/Policy Questions}

The legal controversies surrounding strict liability for used goods marketers largely involve the applicability of enterprise liability theory. Many courts decline to include used goods as part of the "enterprise," which, for new goods transactions, includes suppliers of component parts, manufacturers, wholesalers, retailers, and other intermediaries. Treating the entire production and marketing system as a single enterprise for liability purposes leads to the spreading of risks and costs, providing strong incentives for product safety, and maximizing consumer protection. Having been hurt by a new product, the consumer sues the seller, some form of retailer, who in turn brings other members of the distribution network, including the manufacturer, into the dispute. The court, by applying the Restatement [1965] and common law precedent, then determines who should bear burden of compensating the injured consumer. By denying used goods buyers access to the marketing "enterprise," some courts have effectively required such buyers to carry the responsibility for their injuries, regardless of the manner in which the product became defective.

The extent to which manufacturers/marketers of new products also participate in used goods channels provides another view of enterprise liability theory. From a "first impression" standpoint, one might conclude that manufacturers that are not active in used goods distribution should not be found liable under strict liability. Their involvement could be described as passive, so why should they be liable? This logic is not, however, supported by contemporary views of strict liability for new goods. All channel members, including wholesalers [Bittler $v$. White and Company 1990], brokers [Oscar Mayer v. Mincing Trading 1990], and assemblers [Yost v. Fuscaldo 1991], can be held strictly liable for faulty products. Therefore, mere inactivity should not insulate manufacturers of used goods from strict liability.

Even the Tillman court, which exempted used product sales from strict liability, conceded that under an enterprise analysis, strict liability would "logically follow" [Tillman v. Vance Equipment Co. 1979]. That court ultimately re- 
jected the enterprise approach. Instead, it stated that whatever advantages the application of strict liability might offer in terms of meeting consumers' product expectations and reducing risks through incentives for better products were offset by a desire to hold the strict liability doctrine within manageable bounds [Tillman 1979]. The opinion suggests that strict liability would change the very nature of used goods markets, presumably by pricing the more dangerous items out of the market.

The extension of strict liability to used goods transactions probably would raise prices, as the enterprise theory predicts. If used goods dealers are required to issue warnings that take into account the age, appearance, price, and expected durability of its wares, prices of these products must increase to cover these activities. The same forces yield the same result in new product markets, however. We must decide, as a matter of public policy, if it makes sense to trade off product safety for somewhat lower prices in one market (used goods) and not the other (new products). We must determine if buyers of used products have lower expectations regarding safety than buyers of new products. Are buyers willing to purchase lower-priced used goods and bear the increased risks associated with the abolition of strict liability in these markets? Perhaps some consumers will be able to acquire certain products only if they can buy used goods without the protection of strict liability. As a society are we willing to allow these buyers to make this choice? Ultimately, the question becomes one of protecting consumers and their justifiable expectations of safe products: Is this objective equally compelling for both new and used goods transactions?

Liability for latent defects in used goods raises another troublesome question. California, for example, has rejected strict liability when the seller of a used punch press had the facilities to repair it before the sale, but did not do so [Wilkinson v. Hicks 1982; cf. Meyering v. General Motors Corporation 1990]. Yet California holds all sellers of new goods to strict liability standards for such defects, as do most jurisdictions [Vandermark v. Ford Motor Co. 1964; Restatement 1965, \$402A; Frumer and Friedman 1988, ch. 6]. This extends even to those intermediaries that are expected to pass products along to the next firm in the distribution channel without inspection. It would seem that the same underlying policy objectives that the enterprise liability theory promotes in these and other new product sales ought to apply as well to used goods transactions.

The enterprise argument for strict liability is further bolstered by looking at what constitutes the difference in legal standing between the original and subsequent owners of a product-a simple resale of the item. The product has still been introduced into the channel by the manufacturer, who should bear the responsibility for producing and marketing safe products, regardless of who happens to own them. Strict liability provides an avenue for users to reach such manufacturers/marketers.

Alternatively, the used product channel or enterprise is different from new product channels in a simple but significant way: the presence of the used product seller. The inclusion of this entity within the channel reduces the certainty that a product defect occurred during manufacturing be- cause the used goods seller had the opportunity to handle the product, perhaps even damaging it. Perhaps the used product seller overused the item, thereby making it unsafe for subsequent use. Holding a manufacturer strictly liable when an intermediate owner used the product over an extended period of time essentially makes the manufacturer responsible to later buyers for the actions of earlier buyersan untenable position for the manufacturer. Thus, enterprise liability may place too great a burden on channel members handling used products.

Though courts occasionally hold lessors of used goods strictly liable under enterprise liability arguments [cf. Cintrone v. Hertz Truck Leasing 1965; Ausness 1987], rent-toown firms (RTO) have yet to be tested with strict liability claims. RTO companies differ from traditional leasing firms in that the latter typically provide only financial services and usually do not take physical possession of the goods they lease. RTOs, however, engage in hybrid transactions because their customers can opt out of rental contracts or can apply rental fees toward eventual product ownership [Nehf 1991]. If an RTO specializes in certain product lines, it presumably becomes expert with regard to these products, most likely repairing them when necessary. Such a company thereby possesses knowledge equivalent to that of a routine seller of these products. To absolve RTOs of strict liability simply because they are legally organized as leasing companies provides sellers a tantalizing loophole in product liability law.

The most defensible development regarding liability of used goods sellers is the shielding of one-time sellers from strict liability. To expect someone selling a used lawnmower at a garage sale to guarantee its safety is probably unreasonable - such a seller should not be subject to strict liability. However, the courts need to develop a more clearcut definition of "occasional" seller and a decision rule for weighting the expertise of such sellers.

\section{Marketing/Policy Questions}

Some fundamental marketing- and policy-related questions need to be investigated. First, buyer expectations, for both consumer and industrial segments, regarding used product safety expectations need to be determined for various product markets. It is difficult to imagine that a rational used product buyer would expect an unsafe product, though he or she might anticipate less durability or poorer functional performance than with a new one [Turner $v$. International Harvester Co. 1975]. But what kinds of trade-offs are buyers actually willing to make among safety, durability, performance, and price? Rather than simply asserting opinions on this question, courts should consider properly gathered and analyzed data bearing on the issue.

The used vehicle market might be a useful one within which to make these assessments. Thousands of claims have been filed in the United States for used vehicle-related injuries. Though most of these disputes involve warranty or negligence actions, the interrelatedness of safety, performance, and price surface routinely. Comparisons could be made between judicial assumptions regarding these tradeoffs and the implicit and explicit assumptions made by used vehicle buyers. Used cars are often sold "as is" without 
any seller representations of quality; however, used car dealers cannot simply disclaim their tort liability or obligations regarding implied warranties of fitness. Therefore, an "as is" seller must still inspect the vehicle and place it in reasonable working condition [Korpela 1991; Soehnel 1991].

Current research perspectives could prove to be quite useful here. Bloom [1989], for example, proposes a seven-step analysis to determine the appropriate policy stance regarding information available to consumers in product markets. Among these factors are the harm suffered by consumers and the availability and type of informational cues (internal and external) in the market. Used and new product markets could be examined utilizing a framework comprising these factors. To the extent that no significant differences can be derived when comparing used and new product markets, one could argue that the legal system should make no distinctions.

From the used goods buyer's perspective, Bayus [1991] found that buyers who replace new automobiles "early" are concerned about styling and image, whereas "late" replacement buyers are more concerned about cost. Perhaps the same attributes are of relatively similar importance when comparing different purchasers of used goods that vary in age. That is, those who buy extremely old used products may have no expectations regarding safety; instead, they consider cost and some minimal level of performance. As a matter of public policy, should these people be permitted to forgo product safety without legal recourse?

Relatedly, Mowen and Mowen [1991, p. 57] provide instructive propositions. They hypothesize that people have a strong tendency to choose courses of action with immediate positive outcomes but delayed negative consequences. Used goods and their associated safety levels may illustrate just such a situation. Consumers can choose used products over new goods because of favorable price considerations, incorrectly discounting the greater potential dangers of used items in the future. If these kinds of choices are being made, strict liability could be properly applied, encouraging sellers to improve product safety to protect buyers who make risky decisions. This suggestion assumes, of course, that society should protect these buyers from themselves. Alternatively, if these buyers cannot be forced to understand the risks involved, perhaps they should bear the consequences.

Simply warning prospective used goods buyers, regardless of the legal adequacy of such warnings, may be insufficient. Tanner, Hunt, and Eppright [1991, p. 43] conclude that communicated threats may not actually be perceived by certain audiences as being severe. Buyers with maladaptive coping behaviors, particular consumers with prior safe experiences with used goods, may assuage their fears by thinking, "It won't happen to me." Such thinking provides psychological relief but does nothing to remove potential dangers. These results are consistent with the findings of Mowen and Mowen [1991] and may indicate that, for some people, most warnings will simply be ineffective.

The critical nature of warnings and other forms of information is also relevant from the standpoint of pricing used goods. Tellis and Gaeth [1990] report that increased levels of information lead to "better" choice decisions in terms of new product value (price/quality). Marketers need to determine if this same relationship holds for used products and if the cost of information provision can be passed along to consumers. More importantly from the standpoint of product safety, are consumers willing to choose high-value alternatives that are both low price and low quality/safety if they have adequate information? This is another line of reasoning suggesting that used products buyers may be inclined toward unsafe choices.

If used goods sellers must meet a strict liability standard, they may be restricted in terms of pricing options. Consumers may be unwilling to bear the costs of strict liability and associated insurance premiums. If this is the case, used goods markets may well disappear for some products, at least in the United States. The long-term outcome may be that used products will be increasingly exported to lessdeveloped countries or nations with less stringent liability environments.

The literature on economics of information provides an overview perspective on safety-related information. Economists and others have examined choice decisions under a variety of conditions with respect to risk, information quality, information availability, bargaining power, insurance coverage, etc. [cf. Mazis et al. 1981; Schwartz 1988; Smith 1990]. It would be useful to know if the assumptions made and conclusions reached in new product markets are equally relevant for used goods.

\section{Conclusion}

On balance, extending strict liability to sellers of used goods would serve many of the public policy goals that the doctrine fosters for new product transactions. One difference, a critical one that needs to be investigated empirically, is the level of consumer reliance on the apparent safety of used goods. Do consumers believe that used goods are as safe as new products, or do they equate lower used goods prices with a lesser degree of safety? And, if the latter question is answered affirmatively, should society permit the safety-price trade-off?

Enterprise liability can also be applied to used products channels, but the situation is complicated by the potential intervening and unknown actions of prior owners of used goods. Holding used goods sellers strictly liable essentially makes them responsible for the consequences of actions of persons (prior product owners) over whom they have absolutely no control. Such an outcome creates a legal problem in that it violates the causation requirement of the strict liability doctrine. However, failure to inspect used products or warn buyers about dangers known to the seller seems to be reasonable grounds for strict liability.

Therefore, commercial organizations that regularly market used products should be held strictly liable. The word "regularly" brings such sellers within the conventional used goods enterprise and the failure to inspect or warn can be linked causally with the consumer's injury. Occasional sellers, those not in the business of routinely selling used goods, should not be held strictly liable because they are not a part of the marketing enterprise that redistributes used 
products. Such sellers are also unlikely to be expert with regard to the quality of the items they are selling.

\section{Notes}

1. Restatements are compilations or summaries by the American Law Institute of common (case) law, organized by subject matter, e.g., torts, trusts, contracts. Restatements are not binding on a court, but they do reflect the reasoning of important jurisdictions and the thinking found in particularly well-crafted judicial opinions.

2. This analysis examines strict liability only for physical injuries. Strict liability for economic harm is not covered in this review, nor are products sold as "junk" or "scrap."

3. Privity of contract, described in the classic English case of Winterbottom $v$. Wright [1842], permitted an injured person a tort recovery only from the party that had sold him or her the injurycausing product. A tort action is a legal action for a breach of duty that does not come from a contract, but is imputed by the law. For example, the tort of negligence alleges a breach of duty of reasonable care that common law holds people owe to one another.

4. The relevant portion of the Restatement (Second) of Torts [1965] is \$402A (Special Liability of Seller of Product for Physical Harm to User or Consumer):

(1) One who sells any product in a defective condition unreasonably dangerous to the user or consumer or to his property is subject to liability for physical harm thereby caused to the ultimate user or consumer, or to his property, if

(a) the seller is engaged in the business of selling such a product, and

(b) it is expected to and does reach the user or consumer without substantial change in the condition in which it is sold.

(2) The rule stated in Subsection (1) applies although

(a) the seller has exercised all possible care in the preparation and sales of his product, and

(b) the user or consumer has not bought the product from or entered into any contractual relation with the seller.

5. Virginia has expressly not adopted strict product liability [Sensenbrenner v. Rust, Orling \& Neal 1988]. North Carolina has also refused to impose strict liability on defendants in product liability litigation. This information is based on a 5/3/92 search of the Lexis [1992] legal and periodical electronic libraries.

6. A judgment by the court, prior to a jury verdict, that an issue can be decided as a matter of law given the facts of the case. Either plaintiff or defendant can move for summary judgment.

7. Our review of strict liability for sellers of used products yielded cases from 29 states. A recent review by Korpela [1991] identified 28 states that have heard strict liability allegations related to used products.

8. The concept of enterprise liability was first widely discussed in the marketing literature in commentaries on the DES marketshare litigation [cf. Boedecker and Morgan 1986; Sheffet 1983]. In these cases the defendant "enterprise" was the various competitors marketing DES during certain time periods. Each of these firms was held liable for the collective acts of the enterprise (and each tried to exonerate itself by blaming others) because the fungible nature of DES made it impossible for plaintiffs to identify any one defendant's DES as the harmful substance. Thus, the DES and related cases examined competition among firms at the same horizontal level within competing, similar channels and formed the enterprise among these firms.

In the present discussion the "enterprise" is the traditional vertical channel of distribution. In a product liability action involving a used product, the plaintiff typically sues all members of the channel or enterprise involved in marketing the used product. If the court cannot determine which channel member's actions led to the product causing the plaintiff's injuries, the channel as an enterprise can be held liable. Channel members must then sort out among themselves how to share the burden of compensating the plaintiff. See Priest [1985] for detailed views of vertical and horizontal enterprise liability.

9. Arizona reasserted its acceptance of enterprise liability in Torres v. Goodyear Tire \& Rubber [1990] when a trademark licensor (supplier of allegedly faulty automobile tire) was included in a strict liability action.

\section{References}

Ausness, Richard C. (1987), "'Strict Liability for Chattel Leasing," University of Pittsburgh Law Review, 48 (Winter), 273319.

Bailey v. ITT Grinnell Corporation (1982), 536 F. Supp. 84 (N.D. Ohio).

Barris v. Eddy's Toyota of Wichita, Inc. (1988), No. 86-1970-C, slip op. (D. Kan., October 12).

Bayus, Barry L. (1991), "The Consumer Durable Replacement Buyer," Journal of Marketing, 55 (January), 42-51.

Bennett v. Matt Gay Chevrolet Oldsmobile, Inc. (1991), $200 \mathrm{Ga}$. App. 348, 408 S.E. 2d 111; cert. denied, No. S91C1421, slip op. (Ga., September 6, 1991).

Bevard v. Ajax Manufacturing Company (1979), 473 F. Supp. 35 (E.D. Mich.)

Bittler v. White and Company, Inc. (1990), 203 Ill. App. 3d 26, 560 N.E. 2d 979.

Bloom, Paul N. (1989), "A Decision Model for Prioritizing and Addressing Consumer Information Problems," Journal of Public Policy \& Marketing, 8, 161-80.

Boedecker, Karl A. and Fred W. Morgan (1986), "Intra-Industry Joint Liability: Implications for Marketing," Journal of Public Policy \& Marketing, 5, 72-81.

Brigham v. Hudson Motors, Inc. (1978), 392 A. 2d 130 (N.H.).

Buckbee v. Rockwood Insurance Co. (1989), 542 So. 2d 81 (La. Ct. App.).

Burrows v. Follett and Leach, Inc. (1983), 115 Wis. 2d 272, 340 N.W. 2d 485.

Cintrone v. Hertz Truck Leasing \& Rental Service (1965), 45 N.J. 434, 212 A. 2d 769.

Crandell v. Larkin and Jones Appliance Co., Inc. (1983), 334 N.W. $2 d 31$ (S.D.).

Escola v. Coca-Cola Bottling Co. (1944), 24 Cal. 2d 453, 150 P. $2 d 436$.

Ferragamo v. Massachusetts Bay Transportation Authority (1985), 395 Mass. 581, 481 N.E. 2d 477.

Frumer, Louis R. and Melvin I. Friedman (1988), Products Liability, vol. 2. New York: Matthew Bender.

Galindo v. Precision American Corp. (1985), 754 F. 2d 1212 (5th Cir.), reh'g denied, en banc, 762 F. 2d 1004 (1985 5th Cir., Tex.). 
Gorath v. Rockwell International, Inc. (1989), 441 N.W. 2d 128 (Minn. Ct. App.).

Gordon v. Aztec Brewing Co. (1949), 33 Cal. 2d 514, 203 P. 2d 522.

Greenman v. Yuba Power Products, Inc. (1963), 59 Cal. 2d 57, 27 Cal. Rptr. 697, 377 P. 2d 897.

Grimes v. Axtell Ford Lincoln-Mercury (1987), 403 N.W. 2d 781 (Iowa).

Hadfield, Gillian K. (1990), "Problematic Relations: Franchising and the Law of Incomplete Contracts," Stanford Law Review, 42 (April), 927-92.

Henningsen v. Bloomfield Motors (1960), 32 N.J. 358, 161 A. 2d 69.

Ikerd v. Lapworth (1970), 435 F. 2d 197 (7th Cir., Ind.).

Jordan v. Sunnyslope Appliance, Propane \& Plumbing Supplies Co. (1983), 135 Ariz. 309, 660 P. 2d 1236.

Josephs v. Harris Corp. (1982), 677 F. 2d 983 (3rd Cir.).

Keith v. Russell T. Bundy \& Associates, Inc. (1986), 495 So. 2d 1223 (Fla. Dist. Ct. App.).

Kemp v. Miller (1990), 154 Wis. 2d 538, 453 N.W. 2d 872.

Kodiak Electric Association v. Delaval Turbine, Inc. (1984), 694 P. 2d 150 (Alaska).

Korpela, Allan E. (1991), "Strict Liability in Tort: Liability of Seller of Used Product," Annotated Law Reports 3d, v. 53, New York: Lawyers Co-Operative Publishing Co., 337-55.

LaRosa v. Superior Court of Santa Clara County (1981), 122 Cal. App. 3d 741, 176 Cal. Rptr. 224.

Lexis (1992), LEXIS-NEXIS Library Contents and Alphabetical List. Dayton, OH: Mead Data Central.

MacPherson v. Buick Motor Company (1916), 217 N.Y. 382, 111 N.E. 1050.

Mayberry v. Akron Rubber Machinery Corp. (1979), 483 F. Supp. 407 (N.D. Okla.).

Mazis, Michael B., Richard Staelin, Howard Beales, and Steven Salop (1981), "A Framework for Evaluating Consumer Information Regulation," Journal of Marketing, 45 (Winter), 11-21.

Meyering v. General Motors Corp. (1990), 225 Cal. App. 3d 1198, 275 Cal. Rptr. 346.

Morgan, Fred W. (1987), "Strict Liability and the Marketing of Services vs. Goods: A Judicial Review," Journal of Public Policy \& Marketing, 6, 43-57.

Mowen, John C. and Maryanne M. Mowen (1991), “Time and Outcome Valuation: Implications for Marketing Decision Making," Journal of Marketing, 55 (October), 54-62.

Nehf, James P. (1991), "Effective Regulation of Rent-to-Own Contracts," Ohio State Law Journal, 52 (Summer), 751-845.

Nelson v. Nelson Hardware, Inc. (1991), 160 Wis. 2d 689, 467 N.W. 2d 518, 153 Wis. 2d 218, 450 N.W. 2d 491 (1989 Wis. Ct. App.).

Oscar Mayer Corporation v. Mincing Trading Corp. (1990), 744 F. Supp. 79 (D. N.J.).

Peterson v. Idaho First National Bank (1990), 117 Idaho 724, 791 P. 2d 1303.

Peterson v. Lou Bachrodt Chevrolet Co. (1975), 61 Ill. 2d 17, 329 N.E. 2d 785.
Petrus Chrysler-Plymouth v. Davis (1984), 283 Ark. 172, 671 S.W. $2 d 749$.

Pridgett v. Jackson Iron \& Metal Co. (1971), 253 So. 2d 837 (Miss.).

Priest, George L. (1985), "The Invention of Enterprise Liability: A Critical History of the Intellectual Foundations of Modern Tort Law,' Journal of Legal Studies, 14 (December), 461-527.

Prosser, William L. (1941), Handbook of the Law of Torts. St. Paul, MN: West Publishing Co.

(1960), "The Assault Upon the Citadel (Strict Liability to the Consumer)," Yale Law Journal, 69 (June), 1099-148.

(1966), "The Fall of the Citadel (Strict Liability to the Consumer)," Minnesota Law Review, 50 (April), 791-848.

Rabin, Robert L. (1990), Perspectives on Tort Law, 3rd ed. Boston: Little, Brown.

Realmuto v. Straub Motors (1974), 65 N.J. 336, 322 A. 2 d 440.

Restatement (Second) of Torts (1965), American Law Institute.

Rolph v. EGI Companies (1991), 159 Wis. 2d 518, 464 N.W. 2d 667.

Santiago v. E.W. Bliss Division, Gulf and Western Manufacturing Co. (1985), 201 N.J. Super. 205, 492 A. 2d 1089.

Schwartz, Alan (1988), "Proposals for Products Liability Reform: A Theoretical Synthesis," Yale Law Journal, 97 (February), 353-419.

Sell v. Bertsch and Company, Inc. (1984), 577 F. Supp. 1393 (D. Kan.).

Sensenbrenner v. Rust, Orling \& Neal, Architects, Inc. (1988), 236 Va. 419, 374 S.E. $2 d 55$.

Shapo, Marshall S. (1990), The Law of Products Liability, 2d ed. Boston: Warren, Gorham \& Lamont, chapter 18.

Sheffet, Mary Jane (1983), “Market Share Liability: A New Doctrine of Causation in Product Liability," Journal of Marketing, 47 (Winter), 35-43.

Shirey v. United States (1984), 582 F. Supp. 1251 (D.C. S.C.).

Smith, Darlene Brannigan (1990), “The Economics of Information: An Empirical Approach to Nelson's Search-Experience Framework,' Journal of Public Policy \& Marketing, 9, 11128.

Soehnel, Sonja A. (1991), “Products Liability: Personal Injury or Death Allegedly Caused by Defect in Braking System in Motor Vehicle," Annotated Law Reports 3d. New York: Lawyers CoOperative Publishing Co., 179-223.

Stiles v. Batavia Atomic Horseshoes, Inc. (1992), 1991 N.Y. App. Div. LEXIS 7101 (April 24).

Sukljian v. Charles Ross \& Son Co. (1986), 69 N.Y. 2d 89, 511 N.Y. Supp. 2d 821, 503 N.E. 2d 1358.

Tanner, John F., Jr., James B. Hunt, and David R. Eppright (1991), "The Protection Motivation Model: A Normative Model of Fear Appeals,' Journal of Marketing, 55 (July), 3645.

Tauber-Arons Auctioneers Co., Inc. v. Superior Court of Los Angeles County (1980), 101 Cal. App. 3d 268, 161 Cal. Rptr. 789.

Tellis, Gerard J. and Gary J. Gaeth (1990), “Best Value, PriceSeeking, and Price Aversion: The Impact of Information and Learning on Consumer Choices," Journal of Marketing, 54 (April), 34-45. 
Thompson v. Rockford Machine Tool Co. (1987), 49 Wash. App. 482, 744 P. 2d 357.

Tillman v. Vance Equipment Co. (1979), 286 Ore. 747, 596 P. 2d 1299.

Torres v. Goodyear Tire \& Rubber Co., Inc. (1990), 901 F. 2d 750 (9th Cir.), 786 P. 2d 939 (Ariz. 1990).

Turner v. International Harvester Co. (1975), 133 N.J. Super. 277, 336 A. 2d 62.
Vandermark v. Ford Motor Co. (1964), 61 Cal. 2d 245, 37 Cal. Rptr. 896, 391 P. 2d 168.

Wilkinson v. Hicks (1982), 126 Cal. App. 3d 515, 179 Cal. Rptr. 5.

Williams v. Nuckolls (1982), 644 S.W. 2d 670 (Mo. Ct. App.).

Winterbottom v. Wright (1842), 152 Eng. Rep. 402 (Q.B.).

Yost v. Fuscaldo (1991), 408 S.E. 2d 72 (W. Va.). 